DOI: https://doi.org/10.15407/techned2018.04 $: \underline{070}$

\title{
SERIAL CONNECTING OF RESONANT VOLTAGE INVERTERS FOR HIGH-FREQUENCY INDUCTION HEATING EQUIPMENT
}

Journal

Publisher

ISSN

Issue

Pages
Tekhnichna elektrodynamika

Institute of Electrodynamics National Academy of Science of Ukraine 1607-7970 (print), 2218-1903 (online)

No 4, 2018 (July/August)

$70-73$

\section{Authors}

\section{V.Ya. Hutsaliuk*, O.M. Yurchenko**, I.S. Zubkov, V.P. Pazenko}

Institute of Electrodynamics National Academy of Sciences of Ukraine,

pr. Peremohy, 56, Kyiv, 03057, Ukraine,

e-mail: alfa@ied.org.ua; yuon@ied.org.ua

* ORCID ID : http://orcid.org/0000-0002-2496-1338

** ORCID ID : http://orcid.org/0000-0002-2107-2308

\section{Abstract}

This paper deals with investigation of high-frequency (440 kHz and higher) transistor resonant inverters for induction heating equipment which are designed on the base of serial and parallel inverters connecting. Using of low-voltage high-frequency MOSFETs in inverters whose inputs are connected in series allows to rise frequency and reduce power loss in converters transistors, comparing with high-voltage MOSFET. Inverters with serially connected inputs require circuitry for voltage equalizing; it is suggested necessary equalizing circuitry in the paper. References 10, figures 4. 
Key words: induction heating, high-frequency resonant inverter.

Received: 05.03 .2018

Accepted: 21.03.2018

Published:

\section{References}

1. Kai A. IGBT or MOSFET? Selection practice. Elektronnye komponenty. 2000. № 2. Pp.76-81. (Rus)

2. Yurchenko M.M., Hutsaliuk V.Ya., Shevchenko P.M. Pazenko V.P., Slesarevskiy I.O., Tverdokhlib Yu.O. Parallel - in series connection of high-frequency inverters with output resonant circuit. Tekhnichna Elektrodynamika. Tem. Vyp. Sylova elektronika ta energoefektyvnist. 2005. No 3. Pp. 16-19. (Ukr)

3. AN-5232 New Generation Super-Junction MOSFETs, SuperFET II and SuperFET II Easy Drive MOSFETs for High Efficiency and Lower Switching Noise. 2013. Режим доступу: https ://www.fairchildsemi.com/application-notes/AN/AN-5232.pdf

4. Guillermo Martin Segura. Induction heating converter's design, control and modeling applied to continuous wire heating. Ph.D. dissertation, Dept. d'Enginyeria Electrica, Univ. Politecnica de Catalunya, Barcelona, Spaine. 2012. Pp. 226.

5. Hammad Abo Zied, Peter Mutschler, Guido Bachmann. A Modular IGBT Converter System for High Frequency Induction Heating Applications. PCIM. 2002, 14-16.05., Nuremberg, Pp.-501-506.

6. Hector Sarnago, Oscar Lucia, Arturo Mediano. Multi-MOSFET-Based Resonant Inverter for Improved Efficiency and Power Density Induction Heating Applications. IEEE Transactions of power electronics

2014. Vol. 29. No 8. Pp. 4301-4312.

7. Honggang Sheng, Zheng Chen, Fred Wang, Alan Millner. Investigation of $1.2 \mathrm{kV} \mathrm{SiC}$ 
MOSFET for high frequency high power applications. Applied Power Electronics Conference and Exposition (APEC). 2010

Twenty-Fifth Annual IEEE. Palm Springs, USA. 2010. Pp. 1572-1577.

8. Herasymenko P., Hutsaliuk V., Pavlovskyi V., Yurchenko O. A Software Phase-Locked Loop of Control System of a Series-Resonant Voltage-Source Inverter for Induction Heating Equipment. Proc. IEEE First Ukraine Conference on Electrical and Computer Engineering. Kiev. May-Jun. 2017. Pp. 384-389.

9. Omar El-Nakeeb, Mostafa I Marei, Ahmed A El-Sattar. A High Frequency modular Resonant converter for the Induction Heating. International Journal of Emerging Technology and Advanced Engineering . 2008 Certified Journal. 2013. 3(2): 2013.

10. Y. Jang, M.M. Jovanovic, D.L. Dillman, S. Li, C. Yang. Input-voltage balancing of series-connected converters, Proc. IEEE Appl. Power Electron. Conf. Expo. Fort Worth, TX, USA. 2011. Pp. 1153-1160. 